\title{
From barriers to
}

opportunities: Enabling

investments in resource

efficiency for sustainable

development

\author{
FLORIAN FLACHENECKER, PhD* \\ JUN RENTSCHLER, PhD*
}

Article**

JEL: D24, D61, D62, E60, F18, F64, G20, H23, O13, O31, O44, Q32, Q50

https://doi.org/10.3326/pse.43.4.2

\footnotetext{
* The authors would like to thank Luis Delgado Sancho, Xabier Goenaga, Serge Roudier, Bert Saveyn and two anonymous reviewers for useful comments and suggestions on an earlier draft of the article. Moreover, the authors are grateful to Ingeborg Niestroy, Louis Meuleman, and Katarina Ott for their valuable feedback and support. The authors are responsible for any remaining errors. Disclaimer: The views expressed in this publication are the sole responsibility of the authors and do not necessarily reflect the views of the European Commission, or other organisations the authors are affiliated with. This article is based on the findings published in Flachenecker and Rentschler (2018).

${ }^{* *}$ Received: August 11, 2019
}

Accepted: September 26, 2019

\section{Florian FLACHENECKER}

European Commission, Joint Research Centre, Brussels, Belgium; University College London, Institute for Sustainable Resources, London, UK

e-mail: florian.flachenecker@ec.europa.eu

ORCiD: 0000-0003-4739-3975

Jun RENTSCHLER

The Payne Institute for Public Policy, Denver CO, USA

e-mail: jrentschler@worldbank.org

ORCiD: 0000-0003-0667-1975 


\section{Abstract}

Increasing investments in resource efficiency is considered essential for transitioning towards a sustainable model of economic growth. This article presents evidence on the complex incentives, trade-offs, and challenges associated with the economics and politics of resource efficiency investments, especially in light of the Sustainable Development Goals and the Paris Climate Agreement. By synthesising and evaluating a wide range of empirical evidence, practitioners' insights, and policy perspectives, this article carefully examines the role of resource efficiency in reconciling environmental and economic objectives. It makes particular reference to the investment barriers and transitional implications of moving economies towards more circular and resource efficient pathways. In doing so, it provides a policy-oriented guide and toolbox to help overcome barriers, unlock the economic potential of resource efficiency, and highlight the challenges associated with the resource transition. Overall, this article brings together evidence, aiming to further develop and propose new strategies for improving the efficient use of natural resources to advance the sustainable development agenda.

Keywords: resource efficiency, sustainable development, investments, circular economy, eco-innovation

\section{INTRODUCTION}

The concept of resource efficiency - paraphrased as doing more with less - is receiving increasing attention by researchers, policy makers, the private sector, and the broader public (Bleischwitz et al., 2018). This augmented interest in efficiency increases is not least due to increasingly volatile resource prices, uncertain supply prospects, attempts to revitalise industrial production, and concerns over environmental pressures associated with the use of natural resources. Also related to strategic concerns regarding resource nationalism, scarcity and supply restrictions of critical raw materials with the potential to severely disrupt global value chains, resource efficiency is seen as a viable approach to combining economic objectives, such as competitiveness, employment and productivity growth, with environmental ones, including achieving the pledges made under the Paris Climate Agreement and the Sustainable Development Goals (SDGs).

With a view to implementing the resource transition in practice, i.e. the move towards greater resource efficiency and circularity (Flachenecker and Rentschler, 2018), targeted investments are considered to be a key tool for improving resource efficiency in order to address the aforementioned challenges, while delivering multiple economic and environmental benefits (Peake and Ekins, 2016). In recent years, numerous policy initiatives have highlighted the important role of resource efficiency in national and international agendas:

- The SDGs, in particular SDG 8, to achieve sustainable economic growth, and SDG 12, to ensure sustainable consumption and production patterns. For both SDGs, resource efficiency (or more precisely material productivity) is an indicator to monitor progress; 
- the G7 Alliance for Resource Efficiency and the G20 Resource Efficiency Dialogue;

- the European Union (EU) Roadmap to a Resource Efficient Europe, Raw Materials Initiative, Circular Economy Action Plan, Reflection Paper Towards a Sustainable Europe by 2030, and the recently announced European Green Deal as part of the Political Guidelines for the 2019-2024 European Commission (EC, 2008; 2011; 2015; 2019; von der Leyen, 2019);

- the work of the Organisation for Economic Co-operation and Development (OECD) on resource efficiency, green growth, environmental-economic accounting, and sustainable finance (OECD, 2016; 2017a; 2017b; 2019);

- international financial institutions that provide substantial funding for resource efficiency projects include the European Investment Bank (EIB), the European Bank for Reconstruction and Development (EBRD), and the International Finance Corporation of the World Bank (IFC) (EBRD, 2015; EIB, 2015; IFC, 2011);

- the United Nations have established the International Resource Panel (IRP), a dedicated commission of experts on the issue (UNEP IRP; 2014; 2016; 2017).

All these initiatives are underpinned by national, regional, and local efforts to scale-up resource efficiency investments to divert wastage back into value chains (Bahn-Walkowiak and Steger, 2015). However, despite such high-level efforts to mainstream the resource efficiency agenda, policy measures still lack a coherent, systematic approach and large-scale implementation; even frontrunners such as the EU have yet to deliver on their ambitious goals (Flachenecker, 2015).

Over the next years, technological shifts (e.g., new energy vehicles, renewable energy, 5G infrastructure) and the implementation of the SDGs are bound to increase the demand for certain material resources (Bleischwitz and Flachenecker, 2017). Despite existing evidence for the potential benefits of resource efficiency investments, the improvements have been falling short of expectations and the benefits have been lower than expected. For instance, Flachenecker, Rentschler and de Kleuver (2018) show that globally, resource efficiency has increased by only about $1 \%$ per annum over more than three decades. One central reason for this shortcoming has been that the challenges of wide-scale implementation have been underestimated, as firms and consumers were frequently unable or unwilling to invest in resource efficiency measures (Rentschler, Bleischwitz and Flachenecker, 2018). This raises the question of what has been missing in contemporary resource efficiency efforts to streamline and scale-up investments to make economies more resource efficient and environmental sustainable.

What becomes apparent from the ongoing policy discourse on resource efficiency is that the debate has focused predominantly on goals, and on the benefits of being more resource efficient - but not on how to actually achieve higher efficiency of resource use in practice. The debate focuses on policy and tends to neglect the 
governance dimension; this includes the question about the kind of investments that are chosen to achieve the objectives. Evidence and insights from the academic literature, policy making, and the private sector indicate that resource efficiency investments are associated with multiple challenges. For instance, efficiency investments per se may not necessarily deliver positive net benefits, particularly when negative externalities and the cost of inaction are not accounted for in investment appraisals (Flachenecker, Bleischwitz and Rentschler, 2017). As Flachenecker and Kornejew (2019) show, benefits from resource efficiency investments for some firms, sectors or countries might come at the expense of others, thus reducing the economy-wide effects. Moreover, market barriers, failures and structural inefficiencies often prevent firms and individuals from implementing resource efficiency investments, thereby jeopardising the potential of moving towards resource efficient economies in the first place.

Against this backdrop, this article explores the decisive factors that determine the success of the resource transition and focuses in particular on resource efficiency investments. By critically reviewing the existing literature and synthesising evidence at the country and firm level, it examines how the potential of resource efficiency investments can be unlocked, and what resource efficiency can deliver and what it cannot. It also discusses how resource efficiency investments relate to two crucial and interrelated issues of our time - sustainable development and climate change. Accordingly, it identifies practical measures for overcoming existing barriers and creating incentives for promoting resource efficiency investments.

The article is structured as follows. Section 2 describes the concepts and trends in resource efficiency. Section 3 synthesises and evaluates the evidence on barriers, opportunities, and trade-offs, including the transitional effects of resource efficiency investments. Section 4 describes the role of investors and policy makers in implementing the resource efficiency agenda by analysing their insights in practice. Section 5 indicates existing research gaps, and Section 6 concludes.

\section{CONCEPTS AND TRENDS IN RESOURCE EFFICIENCY}

While improved resource efficiency is a frequently stated objective, general policy discourse does not always reflect a thorough understanding of the specific indicators and policy implications involved. Van Ewijk (2018) introduces resource efficiency by clarifying its concepts, definitions, possibilities, and limitations. The author argues that resource efficiency, and the related concept of the circular economy, are perspectives on the relation between the economy and the natural environment. A conceptual map of resource efficiency describes its main components and clarifies its main purpose: to minimise material inputs, maximise economic outputs, and respect the limits of the environment. The contribution also discusses the linkages between resource use and the economy, and contrasts the economic view on efficiency with the engineering perspective. Finally, the environmental impacts of resources are discussed from a life-cycle perspective. Van Ewijk (2018) concludes by synthesising three major challenges for reconciling environmental 
and economic goals: the lack of alignment between individual company performance and total life-cycle impacts, the environmental rebound effect, and physical limits to efficient and cyclical use of material resources.

Indeed, these challenges are key to explaining the slow progress that countries have made in increasing resource efficiency - despite seemingly strong economic and environmental arguments, and ambitious policy goals. Flachenecker, Rentschler and de Kleuver (2018) demonstrate that monitoring resource efficiency developments is important for identifying efficiency shortfalls, assessing economy-wide effects of resource efficiency improvement potential, and building or maintaining political momentum. To this end, the authors offer an overview of existing indicators and data sources with which to measure resource use and resource efficiency.

Domestic material consumption (DMC) is one of the indicators most frequently used to monitor material resources and material productivity (often referred to as resource efficiency). DMC is part of the indicator set to monitor the SDGs, specifically SDGs 8.4 and 12.2. DMC comprises domestically extracted material resources, adds all imported material resources, and subtracts all exported material resources. Numerous heterogeneous materials are combined by using their weight as a common unit of account, which raises problematic issues; for instance, sand and gravel dominate the DMC indicator in most countries (Flachenecker, Rentschler and de Kleuver, 2018). Another limitation of DMC is that it does not consider the indirect material used that is embodied in, for instance, intermediate goods that are imported. DMC is 'blind' to material leakage - the process of offshoring production and importing intermediate or final goods leading to a lower domestic material consumption and ceteris paribus to higher resource efficiency (Wilts and Bleischwitz, 2012). The related yet more comprehensive indicator raw material consumption (RMC) partially accounts for this shortcoming, but access to data across country and industries, and over time, remains a bottleneck. This is also related to ongoing work on implementing an international consensus on the methodical underpinnings of the RMC indicator and the development of global databases (UNCEEA, 2018).

Flachenecker, Rentschler and de Kleuver (2018) offer an overview of historic trends in resource use, trade, prices, and efficiency from global and regional perspectives. The data on DMC illustrate that resource efficiency has increased over time, albeit slowly. Overall, an increasing efficiency trend is evident both globally and for all considered regional groupings mentioned below. At the global level, resource efficiency can be seen to have increased by $30 \%$ in the period from 1980 to 2010 - i.e., $30 \%$ fewer material resources are used to generate a unit of economic output. This global average means that on average, resource efficiency increases by about $0.9 \%$ per year. More recent calculations for 1970-2015 confirm the global efficiency growth level of about $1.1 \%$ per annum. 
However, regional patterns are heterogeneous. Over the same period, resource efficiency has increased in Africa (8\%), Oceania (56\%), Europe (49\%; EU-28), North America (95\%; N.A.), and Latin America (52\%; L.A.). The large increases in North America and Europe can be partly explained by offshoring materialintensive production and importing intermediate products, which do not reflect all embodied materials, thus artificially depicting large increases in material productivity. In Asia, resource efficiency has slightly decreased between 1980 and 2010 $(-1 \%)$. This drop is mainly triggered by a significant fall in resource efficiency until the mid-1980s, which was predominantly due to a significant shift from agriculture-based economies to more resource intensive manufacturing.

\section{Figure 1}

\section{Resource efficiency in different regions}
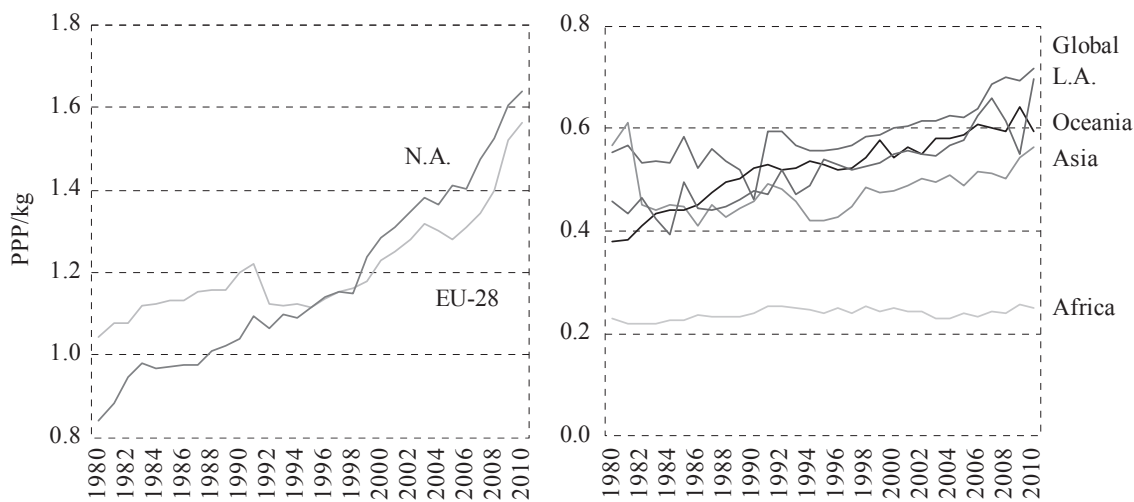

Note: Computed as GDP/DMC, and measured in purchasing power parity in USD per kilogramme of material use.

Sources: (Flachenecker, Rentschler and de Kleuver, 2018; SERI, 2013).

Nevertheless, it is important to note that the observed efficiency increases do not at all offset the increase in absolute material resource use, which more than doubled between 1970 and 2017. More specifically, since the late 1990s, mineral resources have accounted for the biggest share in DMC - approximately $44 \%$ in 2010. Minerals (and to a lesser extent fossil fuels) are the key driver of the rapid growth in DMC - mineral usage nearly tripled in the considered time frame, in particular the use of sand and gravel, which is used in construction. Thus, the relatively low levels of resource efficiency increases are to a large extent due to the infrastructure boom in Asia, especially in China. In short, the observed efficiency improvements have not resulted in a decrease of resource use in absolute terms, thus indicating that the environmental pressures associated with an increase in material resource use in absolute terms are likely to have intensified as well (UNEP IRP, 2010). 
EFFICIENCY

\subsection{TO MAKE PROGRESS, FIRST IDENTIFY BARRIERS OBSTRUCTING ACTION}

Resource efficiency is a policy objective with the potential of delivering a double dividend, yielding both economic and environmental benefits. Yet, slow progress in increasing resource efficiency highlights that economic actors face significant barriers that prevent the investments that are needed for rapid progress. Indeed, the relatively slow adoption of cost-effective technologies - such as building insulation or LED lighting - demonstrates that investments may fail to materialise even when cost-benefit analyses and appraisals of investments in resource efficiency conclude positive net benefits. To understand and categorise these barriers Rentschler, Bleischwitz and Flachenecker (2018) refer to the two Fundamental Theorems of Welfare Economics: The First Fundamental Welfare Theorem suggests perfectly competitive markets as a hypothetical benchmark for investigating the efficiency of actual market outcomes. Such perfectly competitive markets are based on several assumptions, including perfect information, no oligo- or monopolies, no barriers to market entry (or exit), perfect factor mobility, zero transaction costs, and absence of externalities (Varian, 2010).

The violation of any of these assumptions leads to market failures, including information bias, externalities, moral hazard, among others, which create inefficiencies and waste of productive inputs. Rentschler, Bleischwitz and Flachenecker (2018) show that, in practice, there are ubiquitous violations of these assumptions, and firms are faced by a range of market frictions and barriers, which prevent investments in efficiency and low-carbon technologies. For instance, information or capacity constraints can prevent firms from making informed decisions, accessing best available technologies, or operating and maintaining latest technology. Missing or inefficient markets (e.g., for credit) can constrain the implementation of efficiency-enhancing measures. Other missing markets (e.g., for carbon) can lead to severe externalities and excess waste. Large firms and protected industries face little competitive pressure to invest in efficiency gains, especially if protectionist trade policies are in place. This may also mean that the cost of inefficiency is simply passed on to consumers, while firms take no further efficiency-enhancing measures. It tends to be difficult and expensive to adjust physical production infrastructure to frequently changing market conditions, leading to long-term technology lock-in. Overall, these market frictions may mean that investments do not deliver the anticipated resource efficiency gains, or that investors are unable (or unwilling) to undertake them in the first place.

By providing evidence from a large number of countries and regions, Rentschler, Bleischwitz and Flachenecker (2018) demonstrate that resource markets are characterised by inefficiency: in many countries resource productivity remains low, and valuable resources are wasted despite the existence of cost-effective recycling 
technologies. The authors show that the factors that cause and perpetuate such inefficiencies can be categorised in five main types (summarised in Table 1):

i. information availability and access;

ii. technical, managerial, and institutional capacity;

iii. financial markets;

iv. market structure and competition; and

v. public policy and regulation of resource markets.

Each of these categories encompasses a range of complex challenges. For example, several types of information constraints can play a central role in causing inefficiencies and preventing investments: Inadequate monitoring of resource efficiency-related performance indicators at the firm level may make it difficult for firms to identify and address efficiency gaps. Lacking information disclosure on the part of firms makes it difficult for policy makers to design targeted policies and support mechanisms for improving resource efficiency at a wider scale. If firms cannot access relevant information on resource efficient technologies and processes, it is likely to impair their ability to implement effective resource efficiency projects.

Moreover, the different types of investment barriers are often interlinked and can reinforce each other. For instance, the lack of information can lead to an overly negative risk assessment of efficiency-enhancing investments, thus making access to credit even more difficult than it already is. To overcome the resulting financing constraints, public policy interventions and development financing can be crucial to showcase effective solutions and thus stimulate investments in resource efficiency. Section 4.1 provides specific case studies highlighting the aforementioned investment constraints.

In addition, systemic risks and uncertainty can prevent forward looking investment decisions and lead to policy myopia. While such uncertainty can materialise in different forms (e.g., commodity prices, macroeconomic fundamentals, or socio-political conditions), it commonly results in risk averseness and reduced planning horizons. For instance, increased volatility of resource prices increases the perceived uncertainty surrounding future price developments - this in turn can have a substantial impact on the payback periods of resource-related investments and thus lead to the postponement of investment decisions. 
Barriers to investments in resource efficiency

\begin{tabular}{|c|c|c|c|c|c|}
\hline \multirow{10}{*}{$\begin{array}{l}\text { Investment } \\
\text { barriers at } \\
\text { the firm or } \\
\text { govern- } \\
\text { ment level }\end{array}$} & $\begin{array}{l}\text { Information } \\
\text { constraints }\end{array}$ & $\begin{array}{l}\text { Capacity } \\
\text { constraints }\end{array}$ & $\begin{array}{l}\text { Financial } \\
\text { constraints }\end{array}$ & $\begin{array}{l}\text { Market } \\
\text { structures }\end{array}$ & $\begin{array}{l}\text { Fiscal mis- } \\
\text { management }\end{array}$ \\
\hline & \multirow{5}{*}{$\begin{array}{l}\text { Limited } \\
\text { information } \\
\text { on scale and } \\
\text { type of } \\
\text { inefficiencies } \\
\text { (monitoring } \\
\& \text { disclosure) }\end{array}$} & \multirow{5}{*}{$\begin{array}{l}\text { Technical } \\
\text { capacity } \\
\text { Managerial } \\
\text { capacity } \\
\text { Institutional } \\
\text { capacity }\end{array}$} & \multirow{4}{*}{$\begin{array}{l}\text { Uncertain } \\
\text { payoffs } \\
\text { hamper } \\
\text { financing (e.g. } \\
\text { due to lack of } \\
\text { information) }\end{array}$} & $\begin{array}{l}\text { Lack of } \\
\text { competition }\end{array}$ & \multirow{2}{*}{$\begin{array}{l}\text { Subsidies } \\
\text { incentivising } \\
\text { inefficiency }\end{array}$} \\
\hline & & & & Protected & \\
\hline & & & & & Lacking envi- \\
\hline & & & & Trade pro- & $\begin{array}{l}\text { ronmental } \\
\text { regulation }\end{array}$ \\
\hline & & & \multirow{4}{*}{$\begin{array}{l}\text { Non-monetary } \\
\text { benefits not } \\
\text { accounted for } \\
\text { Inadequate } \\
\text { credit markets }\end{array}$} & & \\
\hline & \multirow{4}{*}{$\begin{array}{l}\text { Limited } \\
\text { information } \\
\text { on solutions } \\
\text { (access \& } \\
\text { dissemina- } \\
\text { tion) }\end{array}$} & \multirow{4}{*}{$\begin{array}{l}\text { Lack of } \\
\text { awareness } \\
\text { \& Individual } \\
\text { biases }\end{array}$} & & \multirow{4}{*}{$\begin{array}{l}\text { Principal- } \\
\text { agent } \\
\text { problem }\end{array}$} & \\
\hline & & & & &. \\
\hline & & & & & Other policy \\
\hline & & & $\begin{array}{l}\text { Small scale of } \\
\text { finance needed }\end{array}$ & & $\begin{array}{l}\& \text { regulatory } \\
\text { barriers }\end{array}$ \\
\hline \multirow{3}{*}{$\begin{array}{l}\text { Systemic } \\
\text { risks \& } \\
\text { uncertainty }\end{array}$} & \multirow{2}{*}{\multicolumn{2}{|c|}{$\begin{array}{l}\text { Commodity price volatility } \\
\text { Economic, political and social } \\
\text { stability }\end{array}$}} & \multirow{3}{*}{ Can e } & & \\
\hline & & & & exacerbate ex & S \\
\hline & Policy reliab & & & & \\
\hline
\end{tabular}

Note: Underinvestment in resource efficiency can be due to various market or government failures. Barriers extend from the individual level, to firms and governments. Systemic risks and uncertainty do not necessarily cause inefficiency - but they may exacerbate the adverse effects of existing barriers. ${ }^{1}$

Source: Rentschler, Bleischwitz and Flachenecker (2018).

In many cases the drivers of inefficiency can be traced back to market failures or inadequate public policy. Leading to distorted incentives, and perpetuating preexisting inefficiencies, they can constitute substantial barriers to investments into resource efficiency - even if these investments are found to be cost-effective.

However, on the flipside, the Second Fundamental Welfare Theorem assigns an important role to market interventions (e.g., by governments), stating that they may improve Pareto Efficiency of a given economic allocation by redistributing resources. Especially, the interplay of multiple market inefficiencies and investment barriers means that policy measures need to be designed, not only to help investors cope and overcome these barriers, but also to address the systemic causes of market inefficiencies in the first place (UNEP IRP, 2017). In addition, a prerequisite for effective policy making is a thorough understanding of both the benefits and the potential costs and risks associated with investments in resource efficiency (Flachenecker, Bleischwitz and Rentschler, 2017).

\footnotetext{
${ }^{1}$ The analysis presented in this article builds on the framework presented in Chapter 2 of the World Development Report 2014 (The World Bank, 2013) and Hallegatte and Rentschler (2014).
} 


\subsection{TAKING EFFECTIVE ACTION REQUIRES UNDERSTANDING \\ THE OPPORTUNITIES AND TRADE-OFFS}

Even though increased resource efficiency is considered to yield multiple economic and environmental benefits once barriers do not materialise, it is only gradually increasing across regions, countries, and firms. To investigate the incentives and disincentives for firms to invest in resource efficiency, the literature often relies on costbenefit analyses (CBAs). However, conventional CBAs predominantly consider primary financial implications of investments (i.e., the monetary costs incurred by firms), failing to account for the particular nature of resource efficiency investments.

To this end, Flachenecker, Bleischwitz and Rentschler (2018) introduces a comprehensive cost-benefit framework to assess ex ante the viability of investments in resource efficiency by not only taking financial costs and benefits into account, but to also by considering environmental, non-market, and secondary implications - which are often associated with externalities. The framework summarised in Table 2 is based on a synthesis of the existing academic literature and comprises several components of resource efficiency investments by

i. comparing a business-as-usual scenario (i.e., maintaining the current rate of investments) with a scenario of scaling-up investments in resource efficiency (i.e., firms significantly increase their investments in efficiency improvements),

ii. covering economic and environmental dimensions, due to data availability constraints often restricted to climate change mitigation aspects, and

iii. considering primary and secondary effects (i.e., indirect or second round effects, multiplier, spill-overs, and co-benefits/co-costs).

\section{TABle 2}

Primary and secondary costs and benefits from resource efficiency investments

Potential costs and benefits of investments in resource efficiency

\begin{tabular}{|c|c|c|c|c|}
\hline & \multicolumn{2}{|c|}{ Benefits } & \multicolumn{2}{|c|}{ Costs } \\
\hline & Environmental & Economic & Environmental & Economic \\
\hline \multirow[t]{4}{*}{$\begin{array}{l}\text { Business as } \\
\text { usual }\end{array}$} & & $\begin{array}{l}\text { No initial (and } \\
\text { follow-up) } \\
\text { investments }\end{array}$ & $\begin{array}{l}\text { Environmental } \\
\text { pressures } \\
\text { (negative }\end{array}$ & $\begin{array}{l}\text { Firm level costs } \\
\text { (e.g. exposure to } \\
\text { volatility) }\end{array}$ \\
\hline & & costs & externalities) & \multirow{2}{*}{$\begin{array}{l}\text { Country level } \\
\text { costs (e.g. import } \\
\text { dependency) }\end{array}$} \\
\hline & & $\begin{array}{l}\text { Lower } \\
\text { compliance costs }\end{array}$ & $\begin{array}{l}\text { Reduced human } \\
\text { health and }\end{array}$ & \\
\hline & & $\begin{array}{l}\text { of environmental } \\
\text { regulation }\end{array}$ & natural capital & Lock-ins \\
\hline
\end{tabular}


Potential costs and benefits of investments in resource efficiency

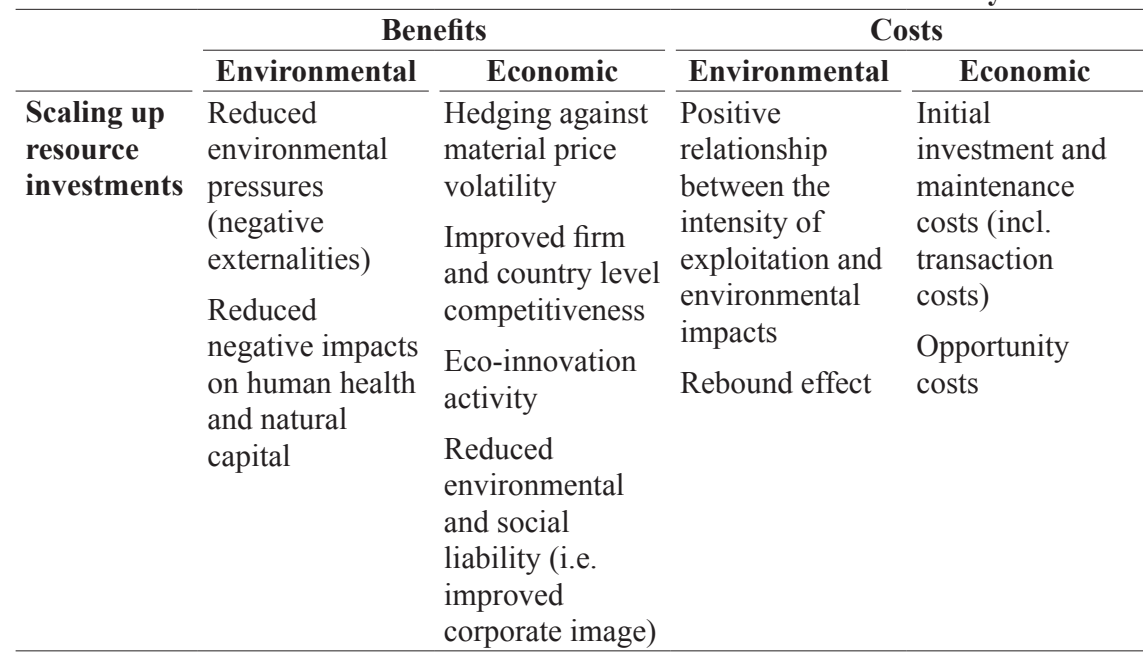

Note: The framework distinguishes between two scenarios (business-as-usual and scaling up resource efficiency investments) and two dimensions (environmental and economic).

Source: Flachenecker, Bleischwitz and Rentschler (2018).

As a case study, this framework is applied to a firm level investment project comprising a range of resource efficiency measures, including energy and material efficiency aspects, in particular measures that are linked to the production techniques of polyvinyl chloride (PVC) plastics. Flachenecker, Bleischwitz and Rentschler (2018) show that for this particular case study the CBA is significantly affected by internalising and monetising environmental externalities (even by applying conservative costs of climate-related damages (Clements et al., 2013)), taking into account the cost of inaction as an informative benchmark, and considering the time horizons of firms since the aforementioned resource efficiency investment project is more likely to result in positive net benefits the longer the planning horizon of the firm is.

In this context, Rentschler, Flachenecker and Kornejew (2018) show that a consistent and practical indicator can help to assess the carbon emission savings of resource efficiency investments, and translate them into monetary savings. This can help firms to identify and prioritise projects, and benchmark their greenhouse gas (GHG) emission savings vis-à-vis other projects and the national emission reduction pathways. Such consistent accounting of corporate emission savings can also help governments to monitor progress towards national efficiency targets or international commitments.

After having considered resource efficiency investments from an ex ante perspective, the ex post view of the effects of resource efficiency investments is equally important from an economic and political perspective. In this context, ex post analyses also provide information on the incentive structure of actors that are considering undertaking resource efficiency investments ex ante. 
The focus here will be the effects of resource efficiency on competitiveness and GHG emissions, given that these are two key policy targets of the resource efficiency agenda (Rosenstock and Flachenecker, 2018). As previously mentioned, the majority of the academic studies investigating these linkages suggest that increasing resource efficiency improves competitiveness as well as supports climate change mitigation efforts (Bassi, Tan and Mbi, 2012; Bleischwitz et al., 2007; Bleischwitz and Steger, 2009; Distelkamp, Meyer and Meyer, 2010; Gilbert et al., 2016; Meyer, Meyer and Distelkamp, 2011; Sakamoto and Managi, 2017; Schröter, Lerch and Jäger, 2011; Walz, 2011).

Flachenecker (2018) critically reviews the existing evidence base on the effects of resource efficiency on firm and country level competitiveness as well as GHG emissions. While the understanding of the effects of resource efficiency on competitiveness and climate change mitigation is growing, there are two prevalent shortcomings in the current evidence base. First, most investigations draw strong conclusions based on case studies, thus limiting the external validity of the findings. Second, studies across firms, sectors, and countries often face methodological problems, including the problematic issue of reverse causality (i.e., it is difficult to isolate whether resource efficiency is the cause and/or the consequence of increased competitiveness). Both issues can severely limit the external and internal validity of the results, in particular since reverse causality can result in biased and inconsistent estimates (Angrist and Pischke, 2009).

The concept of competitiveness is another point of scrutiny since in the policy debates it is often merely used in the context of price competitiveness measured by standard cost and trade indicators, including unit labour costs, the real effective exchange rate, interest rates, and the current account (Siggel, 2006). However, Porter (1990) argues that such measures focusing on costs are insufficient to explain a competitive advantage. For instance, a fall in wages or the exchange rate does not make a country more competitive if one considers that competitiveness follows a much broader definition aiming to raise the standard of living (Snowdon and Stonehouse, 2006). Aiginger (2006) suggests that price competitiveness is a useful measure within the framework of perfectly competitive markets and in developing economies since they often tend to compete in a homogeneous goods market, but it is less useful in imperfect markets and developed economies, as they typically compete in innovations, qualities as well as environmentally sustainable and socially inclusive growth (Rozmahel, Grochová and Litzman, 2014). ${ }^{2}$ Hence, price measures are a relevant factor in determining competitiveness that is, however, by itself insufficient and potentially misleading without being complemented by non-price indicators reflecting welfare creation and its distribution

\footnotetext{
${ }^{2}$ This has previously been discussed in the literature as the Kaldor paradox which originates from relative unit labour costs being positively correlated with the relative market share of manufacturing exports (Kaldor, 1978). Hence, Kaldor (1978) questioned "the relative importance of price (or cost?) competition, as against other 'non-price' factors, such as superiority of design or quality, length and reliability of delivery dates, aftersales service, etc."
} 
Furthermore, Flachenecker (2018) provides empirical evidence on the causal link between resource efficiency and competitiveness as well as GHG emissions for EU countries. Since higher resource efficiency can be a consequence of high competitiveness - and vice versa - the author applies an instrumental variable approach to assess the direction of causality. Both macroeconomic and firm-level data are used to assess the effects of resource efficiency at the country, sector, and firm levels. An indicator set is used to approximate competitiveness on the macroeconomic level, while the market share growth rate approximates competitiveness at the firm level. The results suggest that there is no robust effect of resource efficiency at the country level for most competitiveness indicators, except for wage growth (and to a lesser extent the current account). This suggests that employees might be compensated beyond their labour productivity increase, as part of the resource productivity increase is also passed on to them. At the firm level, however, the results indicate that firms for which the availability of public finance is the main motivation for eco-innovation have a $27 \%$ higher likelihood of improving their resource efficiency. The estimations also provide evidence that increasing resource efficiency causes firm-level competitiveness (i.e., market share growth) to increase by around $12 \%$. The results also show that the probability of reducing GHG emissions for the average firm increases by around $34 \%$ as a result of an increase in resource efficiency.

These empirical findings provide evidence that resource efficiency at the firm level not only improves the competitiveness of firms but also contributes to mitigating climate change. However, the results are heterogeneously distributed across firms, sectors and countries. A further breakdown reveals that certain countries, such as Estonia, Italy, Portugal, and Romania, benefit from resource efficiency improvements, while others do not. Regarding sectors, it becomes apparent that certain material-intensive sectors are more likely to benefit (e.g., waste management, manufacturing of basic metals, wood, and paper).

Therefore, this section draws conclusions on the opportunities and trade-offs of resource efficiency investments with a detailed view on their effects on competitiveness and climate change mitigation. In particular, it is essential to better understand potential trade-offs between firms, sectors, regions, and countries, thus identifying the winners and losers in advancing the economy to a more resource efficient path. Such trade-offs may arise even though CBAs are positive for individual firms and investment barriers do not hinder investments from taking place. Crucially, an important policy insight can be distilled from these results: investments in eco-innovations incentivised by public finance can support certain firms in capturing the benefits from resource efficiency improvements, but the resource transition is likely to have adverse effects on other economic actors, which need to be monitored and mitigated to ensure political support of further pursuing the resource efficiency agenda for sustainable development. 


\subsection{FINANCING EFFICIENCY: THE ROLE OF DEVELOPMENT BANKS AND INSTITUTIONAL INVESTORS}

As Section 3.1 has argued, inefficient resource use is entrenched by a range of mutually reinforcing investment barriers. Together these barriers can form an inefficient equilibrium or lock-in situation in which local actors - including firms and banks - lack the information, capacity, financing, or incentives to invest in costly resource efficiency measures. For instance, without a first mover investor that adopts modern more efficient technologies, other firms will not be incentivised to follow, and banks may be unwilling to offer financing for unknown technologies and project proposals without a proven local track record (Rentschler, 2018). Information barriers may mean that international experience does not translate into local confidence. In this context, external actors and investors - such as multilateral development banks (MDBs) - can play a key role in breaking the lock-in by investing in first movers and thus demonstrating the commercial viability of resource efficiency investments to the wider market. Goovaerts and Verbeek (2018) and Jollands and Hirsch (2018) offer an insight into the rationale of such MDBs with recent examples from the EIB and EBRD, respectively.

Drawing on experience in practice, Goovaerts and Verbeek (2018) identify four challenges from an investor's perspective to the financing of resource efficiency and circular investment projects. First, technological and operational innovation risks often restrict the resource efficiency and circular economy business models to be financed. The issue at stake here is that such business models are often characterised by significant technological and operational risk. In the case of processrelated risks, some processes are based on specific inputs and would not be guaranteed in case of a modification of the feedstock. New technologies have by definition no performance track record and hence entail ramp-up/implementation risks, to which one can add the related uncertainty about operational costs. Many circular projects based on non-technological innovation will likely be less replicable compared to their conventional innovation counterparts, because they may concern different transition styles, forms of innovation, markets, industries, types of companies involved in industrial symbioses, etc. As a result, one would have to wait until several similar projects are implemented before being able to draw conclusions and apply them with respect to other projects appraisals.

Second, collaborative value chain risks are obstacles to investments, but resource efficiency will increasingly require a shift from traditional, linear value chains towards collaborative value networks. For instance, a manufacturer of a recyclable product may not be best positioned to process the return and disassembly of goods. In order to take advantage of the identified opportunity while lacking the required in-house technical or financial capacity, the manufacturer may seek to extend the boundaries of its value chain by entering into a collaborative business relation with a third party who can deliver this activity as a service. However, such collabora- 
tions come with the risk of reducing one's flexibility to make changes in firms' own operations, particularly because such a circular value network will be formed according to the long-term prospects of cooperation. Any loss of flexibility needs to be compensated through the advantages of the collaborative model, such as long and secure business relationships with the relevant partners in the value chain.

Third, resource efficiency investments entail balance sheet implications. In service-based models, the producer remains the owner of its material resources or products for a number of years, enabling easier return, refurbishment, remanufacturing, and reuse. In the circular economy context, it can start to be applied to new asset classes, like lower value consumer products with shorter life (low capital assets). These services or leasing based set-ups usually require substantial upfront investment costs. Securing financing becomes a critical issue, particularly for small companies with no or little revenue who want to rent-out or lease low capital assets. Additionally, products that otherwise would have been sold would, in principle, remain on the company's balance sheet. In most cases, such an increase in the size of the operating assets also leads to a decrease of the average liquidity of the company's overall assets, potentially leading to higher cost of capital (OrtizMolina and Phillips, 2010).

Fourth, cash flow considerations can also impede investors in pursuing resource efficiency investments. In a circular economy, the end-user is less likely to be the end-buyer or ultimate owner which results in completely different cash flow models. In traditional supply chains, products pass from one seller to a buyer through a succession of purchases. In a circular economy, the flow of cash may resemble more that of a lease or rental contract, which results in high upfront costs and small paybacks over longer time periods. Potential upsides consist in an increase in the client base and more stable and predictable revenues in the longer term. This of course depends on and can be influenced by the customers' contracts. Therefore, the volume and diversity of the customer portfolio and the diversity of obligations, and related client and legal risks need to be factored in when assessing the riskiness of the model.

While such factors can deter investors from financing resource efficiency, Goovaerts and Verbeek (2018) conclude that banks and other financial institutions can make an important contribution to the transition towards a circular economy, especially because the linear economy entails market risks (price volatility, depletion), operational risks (lack of resilient value chains), business risks (failure to take advantage of business opportunities), legal risks (polluter pays principle) and reputational risks (credit ratings). In Table 3, the authors provide further details on the types of instruments financial institutions can apply to finance resource efficiency. The first column refers to type of financial actor, and the second and third column provide further details on the kind of products available and the way these could support financing circular projects. In practice, a combination of these instruments is applied to tailor the financing needs to the individual investment projects. 
Table 3

Supply and demand for financing circular business models

\begin{tabular}{|c|c|c|}
\hline \multirow{5}{*}{ Bank finance } & Corporate debt & $\begin{array}{l}\text { Traditional corporate lending to finance } \\
\text { circular businesses with guarantees at } \\
\text { corporate level. }\end{array}$ \\
\hline & Lease & $\begin{array}{l}\text { Can fit pay per use earning models. Applicable } \\
\text { to clients that are creditworthy and products } \\
\text { with predictable residual values in second } \\
\text { hand markets. }\end{array}$ \\
\hline & $\begin{array}{l}\text { Factoring \& supply } \\
\text { chain finance }\end{array}$ & $\begin{array}{l}\text { Can solve the pre-financing issue of pay per } \\
\text { use earning models by selling uncertain future } \\
\text { cash flows to a financial institution. }\end{array}$ \\
\hline & Structured finance & $\begin{array}{l}\text { Can be a financing option for large stand-alone } \\
\text { circular projects. }\end{array}$ \\
\hline & $\begin{array}{l}\text { Balance sheet } \\
\text { reduction through } \\
\text { off balance finance }\end{array}$ & Can solve the issue of balance sheet extension. \\
\hline \multirow{2}{*}{$\begin{array}{l}\text { Capital } \\
\text { markets }\end{array}$} & $\begin{array}{l}\text { Equity finance: } \\
\text { initial public offering }\end{array}$ & \multirow{2}{*}{$\begin{array}{l}\text { Valuable sources of finance for mostly larger } \\
\text { and mature circular businesses that meet the } \\
\text { scale and requirements of the capital markets. }\end{array}$} \\
\hline & $\begin{array}{l}\text { Debt finance: } \\
\text { Green bonds }\end{array}$ & \\
\hline $\begin{array}{l}\text { Impacts } \\
\text { investors }\end{array}$ & & $\begin{array}{l}\text { Most circular businesses are still at their pilot } \\
\text { stage, are not profitable yet, or are lacking } \\
\text { a track record. Non-commercial finance can } \\
\text { bridge the gap from pilot stage to growth } \\
\text { stage, as they have a longer-term view, more } \\
\text { 'patient' investors, and have a risk/return that } \\
\text { is less linked. }\end{array}$ \\
\hline $\begin{array}{l}\text { Venture capital, } \\
\text { private equity, } \\
\text { family offices }\end{array}$ & & $\begin{array}{l}\text { Finance source for the many start-up } \\
\text { businesses in the circular economy. However, } \\
\text { their requirement for high growth and } \\
\text { relatively fast payback horizons might limit } \\
\text { suitability for circular businesses. }\end{array}$ \\
\hline $\begin{array}{l}\text { Near banks like } \\
\text { Google, Apple, } \\
\text { Amazon etc. } \\
\end{array}$ & & $\begin{array}{l}\text { Offer new payment facilities and possibly } \\
\text { working capital solutions. }\end{array}$ \\
\hline \multirow{2}{*}{ Crowdfunding } & Peer2Peer lending & \multirow{2}{*}{$\begin{array}{l}\text { Finance source for circular businesses that } \\
\text { involve the (local) community or those based } \\
\text { upon ideas that appeal to the crowd. }\end{array}$} \\
\hline & Equity investment & \\
\hline
\end{tabular}

Source: (Goovaerts and Verbeek, 2018).

Goovaerts and Verbeek (2018) conclude that to support projects with a positive economic and societal rate of return that are not privately financed (e.g., due to market failures), carefully calibrated public support can provide bridge capital, thereby reducing risks for private investors and lower the associated interest rate costs for the lenders. The aim of these interventions is to foster catalytic effects on potential co-investors and attract more funding to projects of high value added. In this context, innovative public-private risk sharing instruments, or blending of public and private sources of funding, thus going beyond traditional grants, are important to leverage on circular investments. Through the support of the public side, the 
private investor could provide advantageous debt finance by accepting higher risk profiles or less collateral, or by charging lower interest rates or providing similar advantages compared to their ordinary financing activities. To limit the public exposure to risk, a contractually agreed cap on portfolio losses could be applied.

Jollands and Hirsch (2018) provide a perspective from EBRD by showcasing investment strategies and practical examples of investments that deliver improved resource efficiency, especially at the firm level. The authors provide insights into and understanding of what is required, by businesses and banks, to improve resource efficiency in firms around the world. The authors argue that a mix of financial support measures (e.g., credit line technology selector, engaging local banks) and on the ground policy improvements (e.g., minimum energy efficiency labels, training and capacity, waste tariff reform) would support the further uptake of resource efficiency investments. With a focus on financial infrastructure and project finance, the authors conclude that it is important to create an environment in which businesses are incentivised to invest in resource efficiency projects. The role of MDBs in enabling resource efficiency investments is particularly crucial since it can showcase the financial and environmental viability of resource efficiency projects, especially in developing or emerging economies.

\subsection{POLICY MEASURES FOR ENHANCING RESOURCE EFFICIENCY}

Overall, the insights presented in this article suggest that even when investment projects are implemented and resource efficiency is increased successfully, this does not guarantee the full realisation of economic and environmental benefits. As argued in Hughes and Ekins (2018), integrated policy and regulatory strategies are needed that go beyond a focus on investments, and align resource efficiency objectives with the wider sustainable development, climate change mitigation, and circular economy agendas. The authors show that a tailored combination of policy measures is needed, comprising the following aspects:

i. Addressing the lack of information or imperfect information through information policies (e.g., energy efficiency labelling);

ii. Addressing financial risk by creating more favourable conditions for long term investment (e.g., through MDBs);

iii. Addressing the hidden costs which impede identification of cross-firm synergies, by establishing knowledge transfer networks and industrial symbiosis programmes (e.g., the industrial symbiosis component of the Japanese Eco-Town Programme);

iv. Addressing split incentives through regulation (e.g., extended producer responsibility schemes);

v. Addressing the incomplete pricing of externalities through fiscal measures (e.g., landfill tax);

vi. Addressing the lack of private sector investment in innovation due to risk perception, through public investment in $\mathrm{R} \& \mathrm{D}$, creation of research clusters, and forward procurement (e.g., product specifications and green public procurement). 
In this context, Rentschler, Bleischwitz, and Flachenecker (2018) also argue that the variety of investment barriers to improving efficiency suggests the need for a carefully designed package of complementary policy measures. Ambitious resource efficiency targets set by governments will require tailored measures that can help a firm quickly to overcome investment barriers. At the same time the market and government failures that led to investment barriers in the first place must also be addressed, as they will create new and perpetuate existing inefficiencies (Cagno et al., 2013; Sudhakara Reddy, 2013). This is important in order to achieve a larger scale enhancement of resource and energy efficiency, as well as to sustain efficiency gains and green development over time (Bleischwitz, 2012). Sorrell (2003) argue that carbon pricing can be at the heart of such a policy mix, though trade-offs due to policy interactions may exist. Fankhauser et al. (2011) also suggest that combining multiple climate policy instruments entails risks to efficiency - though they mainly focus on combing different carbon pricing instruments, rather than complementary policies more broadly.

Essentially, this prescribes two complementary policy approaches to tackling firms' investment barriers: (i) Addressing the immediate Symptoms of investment barriers, i.e., help firms to deal with and overcome the adverse effects of preexisting investment barriers (e.g., supply specific technical information needed for increasing energy efficiency in a firm/sector); and (ii) addressing the underlying Causes of investment barriers, i.e., resolving the pre-existing market failures and structural inefficiencies that cause the barriers in the first place (e.g., fix overall information infrastructure and technology dissemination systems). These approaches are not mutually exclusive, and both need to be part of a comprehensive strategy for resource efficiency.

Policy measures for strengthening resource efficiency can broadly be distinguished into micro and macro level interventions: i.e. firm level measures, which support firms in overcoming the above-mentioned investment barriers, and more comprehensive macro level measures, which reform the structural deficiencies and inefficiencies of the overall system (see Table 4).

Micro level measures directly support specific firms with the implementation of efficiency projects, modernisation and green innovation - especially when firms may otherwise struggle to implement necessary changes. Such support comprises both technical assistance (especially for building capacity), as well as financial assistance, which can enable concrete efficiency-enhancing measures at the firm level in the presence of financial barriers (Anderson and Newell, 2004). The European Integrated Pollution Prevention and Control Bureau of the Joint Research Centre of the European Commission is one example for developing and reviewing best available techniques (BAT) reference documents that help reducing the information constraints of firms and industries by identifying and promoting BAT for resource efficiency for the energy industry, refineries, manufacturing of metals, waste treatment and incineration, and chemical production in Europe (European Commission, 2018b). Over- 
all, micro level measures can be effective in facilitating quick efficiency gains in targeted industries, and may (eventually) lead to a bottom-up improvement of sectorwide environmental performance. Firm-level measures are however less suitable for resolving the structural causes of barriers to green investment.

Macro-level interventions should implement policy and regulatory reforms, which correct mis-aligned incentive structures, and improve the investment environment within which firms operate (Sudhakara Reddy, 2013). As at the firm level, macro measures comprise non-monetary and monetary ones, both of which are necessary to address the underlying causes of investment barriers.

\section{TABLE 4}

Policy measures and interventions

Micro (i.e. firm) level

Macro level

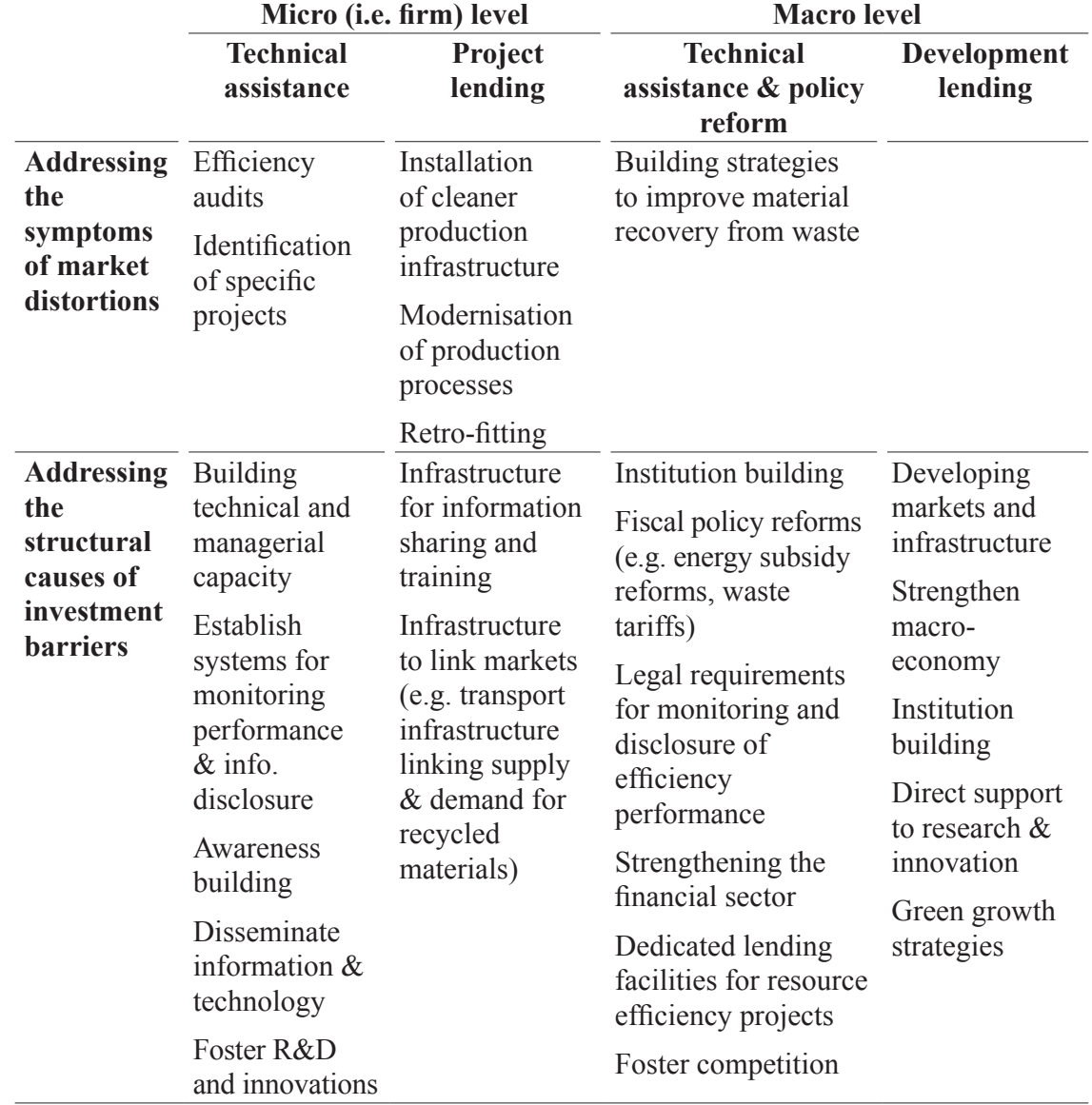

Note: This typology presents a toolbox for micro and macro interventions for enhancing resource efficiency. The categorisation is indicative and not definite: For instance, micro level measures may eventually lead to more structural macro improvements.

Source: Rentschler, Bleischwitz and Flachenecker (2018). 
Joined-up policy is also required to consider sectors that may unavoidably lose out in a resource efficient transition. As Section 3.2 suggests, innovative firms in resource-intensive sectors are likely to benefit from the transition, while others might lag behind. Compensation and incentivising retraining to increase mobility and diversify skill sets may be able to reduce the socioeconomic impacts of potential sectoral and regional declines, and may help to reinvigorate local economies based on more resource efficient activities. Joined-up policy may also be critical for limiting the impact of the rebound effect. In conclusion, an integrated policy approach that recognises complex economic incentives and trade-offs, supports decision makers on the ground, promotes innovation in technologies and processes, and offers a clear long-term direction of travel, will have a greater chance of achieving resource efficiency.

\section{FUTURE RESEARCH NEEDS}

This article also highlights that the understanding and evidence base on resource efficiency is far from complete. To enable effective evidence-based policy making, further research is required in several areas. In this section, based on Flachenecker and Rentschler (2018), we highlight three priority areas in which further work is needed to improve the understanding of the implications of the resource transition.

\subsection{DATA AVAILABILITY, QUALITY, AND COMPARABILITY}

Having access to high-quality, relevant, and comparable data is crucial for ensuring evidence-based policy making. In short, data are the basis for essentially every analysis on the resource transition. Since the systematic analysis of resource flows and their role in economic systems is still a relatively recent field of research, comprehensive databases are also crucial for strengthening current methodologies for calculating resource indicators, and testing the various underlying assumptions and approaches.

Flachenecker, Rentschler and de Kleuver (2018) emphasise that reliance on accounts and indicators that use different methodologies either across time or countries is problematic for any systematic analysis. This is particularly relevant for assessing the indirect resource use embodied in trade, as dependable data across countries are often sparse (on the sector and firm level) or inconsistent with national data. While there is work underway across international agencies to improve and harmonise existing data sources and calculation methods, these efforts need to be recognised and adopted through efforts at the national level. This work is expected to usefully support the monitoring of the SDGs 8 and 12. Related research provides further insights into the sectoral distribution of GHG emissions in a consistent and internationally comparable manner with a view to inform the Paris Climate Agreement with more granular insights (Flachenecker, Guidetti and Pionnier, 2018). 
In addition to the harmonisation of databases, their scope and coverage also require expansion. In particular, accounting for material resources and deriving conventional material resource indicators need to be complemented by consistently taking secondary material resource use (recycling as well as up- and downcycling) into account. This would provide more comprehensive measures, not only to monitor developments towards greater resource efficiency, but also of the circularity with which resources are used throughout the economy. Eurostat's material use rate is a step in this direction (European Commission, 2018a), while facing several limitations. For instance, the underlying assumption that more secondary materials substitute primary raw materials, thus avoiding the extraction of primary material is generally correct, but it is important to consider the spatial dimension since empirical analysis suggests that secondary raw materials might substitute for imports of secondary raw materials but not of primary raw materials (Dussaux and Glachant, 2015; European Commission, 2018c).

\subsection{IDENTIFY POTENTIALLY ADVERSELY AFFECTED SECTORS AND REGIONS OF THE RESOURCE TRANSITION}

Future research is also required to study in much greater detail the types of firms, sectors, and regions that may be adversely affected by the resource transition. Crucially, a clearer understanding needs to be developed of why certain actors may fail to benefit from increased resource efficiency. This information is critical for finding adequate responses for affected sectors and regions (Flachenecker, 2018; Hughes and Ekins, 2018). Simply emphasising the positive effects while overlooking downside risks for certain firms, sectors, and regions will ultimately undermine trust in the very institutional framework that could support those affected not only in coping with but also in benefitting from this transition in the medium to long-term.

Possible responses may include the acceleration or slowing of the transition for certain sectors, and supporting the re-training and re-employment of the affected work force. Such mitigating measures will be critical for ensuring a seamless transition towards a resource-efficient and circular growth model, and help to prepare the work force for future demand related to skills in the areas of resource efficiency and circular business models. This in turn could enable local communities to be at the forefront of the resource transition. However, successfully moderating this transition will require first of all a detailed understanding of the expected effects certain groups in society will be confronted with.

\subsection{EXPLORING THE ROLE OF RESOURCE EFFICIENCY IN ACHIEVING A CIRCULAR ECONOMY AND SUSTAINABLE DEVELOPMENT}

While resource efficiency investments tend to be limited to individual production units, firms, or sectors, the transition towards a circular economy requires targeted measures to integrate supply and value chains throughout the entire economy. Further research can help to improve our understanding of how incremental firm-level improvements in resource efficiency can contribute to such a systemic transition 
towards a circular economy. This can enable policy makers to reconcile resource efficiency policies with longer-term objectives for increasing the circularity of resource flows across sectors, and to design adequate policy strategies and targets.

Moreover, further case-specific research is needed to understand how resource efficiency measures can contribute to improving environmental, social, and economic sustainability. The evidence presented in this article suggests that the economic and environmental net benefit of resource efficiency measures is not always straight forward to determine, and varies significantly from case to case, sector to sector, and country to country. In addition, further research is required to understand how the wide-ranging priorities under the SDGs may increase the demand for resources and intensify existing scarcities (Bleischwitz and Flachenecker, 2017). For instance, the objective of scaling up renewable energy generation and storage is likely to significantly increase the demand for certain resources and possibly interfere with the goal of reducing resource dependencies. Thus, the design of resource efficiency strategies must be aligned with technological changes and the evolving needs and priorities of the sustainable development agenda.

\section{CONCLUSIONS}

High and volatile resource prices, uncertain supply, rising demand and environmental impacts - various factors are putting increasing pressure on policy makers, researchers, firms, and investors to explore pathways towards sustainable and efficient resource management. An increase in resource efficiency is considered to be an answer to these challenges.

This article outlines the numerous initiatives on the international level that have highlighted the important role of resource efficiency in policy agendas. However, while political support for resource efficiency is important, trends show that it is by no means sufficient. Indeed, the article shows that global progress in enhancing resource efficiency is outpaced by an ever-increasing demand for material resources. It has been shown that barriers and the ubiquitous prevalence of market failures and distortions prevent resource efficiency investments from taking place. Furthermore, the article provides evidence for the complexity of evaluating costs and benefits of resource efficiency investments, which need to be benchmarked to the 'cost of inaction' and external effects are to be internalised.

Findings are also presented on the effects of resource efficiency investments on competitiveness and GHG emissions in EU countries, at both the macroeconomic and the firm level, suggesting a heterogeneous picture. While firms in certain sectors are likely to gain from the resource transition, other parts of the economy may see adverse impacts, thus raising the question of how short-term distributional effects can be mitigated. Therefore, nuanced conclusions on the effect of resource efficiency on competitiveness and climate change mitigation need to be drawn. In particular, it seems essential to conduct further research on the potential trade-offs at the firm, sector, country, and regional levels, thus identifying the winners and losers in 
the progress of the economy to a more resource efficient path. From a policy perspective, it is essential to develop measures to mitigate adverse effects in order to ensure the continued political support for pursuing the resource efficiency agenda.

The article further provides insights from institutional investors on the challenges and strategies to overcome investment barriers to enhance resource efficiency. Indeed, especially in developing and emerging economies, multilateral development banks can play a crucial role in resolving information barriers, facilitating technology transfer, mitigating financing constraints, and thus encouraging first movers. However, as this article outlines, governments ultimately play the crucial role in enabling resource efficiency investments by adopting integrated policy measures that address the causes and symptoms of resource inefficiency, and thus establish the necessary business environment to unlock the potential of resource efficiency investments.

Overall, this article, based on Flachenecker and Rentschler (2018), outlines the complex economic incentives and trade-offs associated with resource efficiency investments. It provides an analytical framework for assessing the prospects and viability of such investments in practice; and proposes policy strategies for overcoming investment barriers and boosting resource efficiency investments. In doing so, this article aims to guide future research, and contribute to the design and implementation of more effective resource efficiency policies - and thus facilitate the transition to more resource-efficient and sustainable development pathways. Close collaboration among researchers, practitioners, policy makers, and the broader public is likely to be of crucial importance in combining the necessary evidence base, scale, and democratic legitimacy in successfully steering the resource transition.

\section{Disclosure statement}

No potential conflict of interest was reported by the authors. 


\section{REFERENCES}

1. Aiginger, K., 2006. Competitiveness: From a dangerous obsession to a welfare creating ability with positive externalities. Journal of Industry, Competition and Trade, 6, pp. 161-177. https://doi.org/10.1007/s10842-006-9475-6

2. Anderson, S. T. and Newell, R. G., 2004. Information programs for technology adoption: the case of energy-efficiency audits. Resource and Energy Economics, 26(1), pp. 27-50.

3. Angrist, J. D. and Pischke, J.-S., 2009. Mostly Harmless Econometrics: An Empiricist's Companion. Princeton University Press. Princeton, USA: Princeton University Press.

4. Bahn-Walkowiak, B. and Steger, S., 2015. Resource Targets in Europe and Worldwide: An Overview. Resources, 4(3), pp. 597-620. https://doi.org/ $10.3390 /$ resources4030597

5. Bassi, A. M., Tan, Z. and Mbi, A., 2012. Estimating the impact of investing in a resource efficient, resilient global energy-intensive manufacturing industry. Technological Forecasting and Social Change, 79(1), pp. 69-84. https://doi. org/10.1016/j.techfore.2011.05.011

6. Bleischwitz, R. [et al.], 2007. The relation between resource productivity and competitiveness. Wuppertal Institute.

7. Bleischwitz, R. and Steger, S., 2009. Decoupling GDP from resource use, resource productivity and competitiveness: a cross-country comparison. In R. Bleischwitz et al., eds. Sustainable growth and resource productivity: economic and global policy issues. Sheffield, UK: Greenleaf Publishing, pp. 172-193.

8. Bleischwitz, R., 2012. Towards a Resource Policy - Unleashing Productivity Dynamics and Balancing International Distortions. Mineral Economics, 24(2), 135-144.

9. Bleischwitz, R. and Flachenecker, F. (2017). Sustainable resources: Managing markets, increasing efficiency and establishing partnerships. In von Hauff, M. and Kuhnke, C., eds. Sustainable Development Policy: A European Perspective. London: Routledge. https://doi.org/10.4324/9781315269177

10. Bleischwitz, R. [et al.], 2018. Resource nexus perspectives towards the United Nations Sustainable Development Goals. Nature Sustainability, 1(12), 737-743. https://doi.org/10.1038/s41893-018-0173-2

11. Cagno, E. [et al.], 2013. A novel approach for barriers to industrial energy efficiency. Renewable and Sustainable Energy Reviews, 19, 290-308. https:// doi.org/10.1016/j.rser.2012.11.007

12. Clements, B. [et al.], 2013. Energy Subsidy Reform: Lessons and Implications. International Monetary Fund (Vol. 1). Washington: IMF.

13. Distelkamp, M., Meyer, B. and Meyer, M., 2010. Quantitative und qualitative Analyse der ökonomischen Effekte einer forcierten Ressourceneffizienzstrategie Abschlussbericht zu AP5. Ressourceneffizienz Paper 5.6. Wuppertal, Germany.

14. Dussaux, D. and Glachant, M., 2015. How much does recycling reduce imports? Evidence from metallic raw materials. 33 Working Papers Series, Working paper, No. 15-CER-03. https://doi.org/10.1080/21606544.2018.1520650 
15. EBRD, 2015. Green economy transition approach-As approved by the Board of Directors at its meeting on 30 September 2015. London, EBRD.

16. European Commission, 2008. The raw materials initiative - meeting our critical needs for growth and jobs in Europe COM(2008) 699 final. Communication from the Comission to the European Parliament and the Councel. Brussels: The European Commission.

17. European Commission, 2011. A Roadmap for moving to a competitive low carbon economy in 2050-COM(2011) 112 final (Vol. COM(2011)). Brussels: The European Commission.

18. European Commission, 2015. Closing the loop - An EU action plan for the Circular Economy - COM(2015) 614/2 (2015). Brussels: The European Commission. https://doi.org/10.1017/CBO9781107415324.004

19. European Commission, 2018. Circular material use rate - (cei_srm030) metadata. Statistical Office of the European Communities. Luxembourg.

20. European Commission, 2018. Commission Implementing Decision (EU) 2018/1147 - establishing best available techniques (BAT) conclusions for waste treatment, under Directive 2010/75/EU of the European Parliament and of the Council, 2018/1147. Official Journal of the European Union § (2018).

21. European Commission, 2018. Measuring progress towards circular economy in the European Union - Staff Working Paper - SWD(2018) 17 final. Brussels: European Commission.

22. European Commission, 2019. Reflection Paper - Towards a Sustainable Europe By 2030. Brussels: European Commission.

23. Fankhauser, S., Hepurn, C. and Park, J., 2011. Combining Multiple Climate Policy Instruments: How Not To Do It. Climate Change Economics, 1(3), pp. 209-225. https://doi.org/10.1142/s2010007810000169

24. Flachenecker, F., 2015. Crossing the divide: Long held up as the world leader in resource efficiency, the European Union is a work in progress. Corporate Waste Solutions, 1(1), pp. 1-3.

25. Flachenecker, F., 2018. The effects of resource efficiency on competitiveness and climate change mitigation - the role of investments. In F. Flachenecker and J. Rentschler, eds. Investing in Resource Efficiency: The Economics and Politics of Financing the Resource Transition. Heidelberg: Springer, pp. 139-167. https://doi.org/10.1007/978-3-319-78867-8_7

26. Flachenecker, F., Bleischwitz, R. and Rentschler, J. E., 2017. Investments in material efficiency: the introduction and application of a comprehensive costbenefit framework. Journal of Environmental Economics and Policy, 6(2), pp. 107-120. https://doi.org/10.1080/21606544.2016.1211557

27. Flachenecker, F., Bleischwitz, R. and Rentschler, J., 2018. The introduction and application of a comprehensive cost-benefit framework for resource efficiency investments. In F. Flachenecker and J. Rentschler, eds. Investing in Resource Efficiency: The Economics and Politics of Financing the Resource Transition. Heidelberg: Springer, pp. 87-104. https://doi.org/10.1007/978-3319-78867-8_5 
28. Flachenecker, F., Guidetti, E. and Pionnier, P.-A., 2018. Towards global SEEA Air Emission Accounts: Description and evaluation of the OECD methodology to estimate SEEA Air Emission Accounts for CO2, $\mathrm{CH} 4$ and $\mathrm{N} 2 \mathrm{O}$ in Annex-I countries to the UNFCCC. Paris: OECD. https://doi.org/10.1787/ $7 \mathrm{~d} 88 \mathrm{dfdd}-\mathrm{en}$

29. Flachenecker, F. and Kornejew, M., 2019. The causal impact of material productivity on microeconomic competitiveness and environmental performance in the European Union. Environmental Economics and Policy Studies, 21(1), pp. 87-122. https://doi.org/10.1007/s10018-018-0223-z

30. Flachenecker, F. and Rentschler, J., 2018. Investing in Resource Efficiency The Economics and Politics of Financing the Resource Transition. New York: Springer. https://doi.org/10.1007/978-3-319-78867-8

31. Flachenecker, F., Rentschler, J. and de Kleuver, W., 2018. Monitoring Resource Efficiency Developments: Indicators, Data, and Trends. In F. Flachenecker and J. Rentschler, eds. Investing in Resource Efficiency: The Economics and Politics of Financing the Resource Transition. Heidelberg: Springer, pp. 31-49. https://doi.org/10.1007/978-3-319-78867-8_3

32. Gilbert, P. [et al.], 2016. The role of material efficiency to reduce CO2 emissions during ship manufacture: A life cycle approach. Marine Policy, 75, pp. 227-237. https://doi.org/10.1016/j.marpol.2016.04.003

33. Goovaerts, L. and Verbeek, A., 2018. Sustainable Banking: Finance in the Circular Economy. In F. Flachenecker and J. Rentschler, eds. Investing in Resource Efficiency: The Economics and Politics of Financing the Resource Transition. Heidelberg: Springer, pp. 191-208. https://doi.org/10.1007/978-3319-78867-8_9

34. Hallegatte, S. and Rentschler, J., 2014. Risk Management for DevelopmentAssessing Obstacles and Prioritizing Action. Risk Analysis, 28. August, 2014. https://doi.org/10.1111/risa.12269

35. Hughes, N. and Ekins, P., 2018. The Role of Policy in Unlocking the Potential of Resource Efficiency Investments. In F. Flachenecker and J. Rentschler, eds. Investing in Resource Efficiency: The Economics and Politics of Financing the Resource Transition. Heidelberg: Springer, pp. 247-280. https://doi. org/10.1007/978-3-319-78867-8_12

36. IFC, 2011. Resource Efficiency in the Ferrous Foundry Industry in Russia. Washington DC: International Finance Corporation.

37. Jollands, N. and Hirsch, P., 2018. Mobilising Finance for Resource Efficiency Investments. In F. Flachenecker and J. Rentschler, eds. Investing in Resource Effciency: The Economics and Politics of Financing the Resource Transition. Heidelberg: Springer, pp. 211-224. https://doi.org/10.1007/978-3-319-78867-8_10

38. Kaldor, N., 1978. The effect of devaluations on trade in manufactures. Further Essays on Applied Economics, pp. 99-118.

39. Lehner, F., Bierter, W. and Charles, T., 1999. Resource Productivity, Competitiveness, and Employment In The Advanced Economies. Cheltenham: Edward Elgar. 
40. Meyer, B., Meyer, M. and Distelkamp, M., 2011. Modeling green growth and resource efficiency: new results. Mineral Economics, 24(2-3), pp. 145-154. https://doi.org/10.1007/s13563-011-0008-3

41. OECD, 2016. Policy Guidance on Resource Efficiency - OECD Publishing. Paris: OECD. http://dx.doi.org/10.1787/9789264257344-en

42. OECD, 2017a. Green Growth Indicators 2017. Paris: OECD. https://doi.org/ 10.1787/9789264202030-en

43. OECD, 2017b. Investing in Climate, Investing in Growth. Paris: OECD. http:// dx.doi.org/10.1787/9789264273528-en

44. OECD, 2019. Global Material Resources Outlook to 2060 - Economic Drivers and Environmental Consequences. Paris: OECD. https://doi.org/10.1787/ 9789264307452-en

45. Ortiz-Molina, H. and Phillips, G. M., 2010. Asset Liquidity and the Cost of Capital. NBER Working Paper Series, No. 15992.

46. Peake, S. and Ekins, P., 2016. Exploring the financial and investment implications of the Paris Agreement. Climate Policy, pp. 1-16. https://doi.org/10.108 0/14693062.2016.1258633

47. Porter, M. E., 1990. The Competitive Advantage of Nations. Harvard Business Review, (March-April).

48. Reinert, E. S., 1995. Competitiveness and its predecessors - a 500-year crossnational perspective. Structural Change and Economics, 6(1), 23-42.

49. Rentschler, J., 2018. Fossil Fuel Subsidy Reforms: A Guide to Economic and Political Complexity. London: Routledge.

50. Rentschler, J., Bleischwitz, R. and Flachenecker, F., 2018. On imperfect competition and market distortions: the causes of corporate under-investment in energy and material efficiency. International Economics and Economic Policy, 15(1), pp. 159-183. https://doi.org/10.1007/s10368-016-0370-2

51. Rentschler, J., Flachenecker, F. and Kornejew, M., 2018. Assessing carbon emission savings from corporate resource efficiency investments: an estimation indicator in theory and practice. Environment, Development and Sustainability. https://doi.org/10.1007/s10668-018-0222-z

52. Rosenstock, M. and Flachenecker, F., 2018. Enabling Resource Efficiency Investments - A Review and Outlook of the Resource Efficiency Agenda of the European Union. In F. Flachenecker and J. Rentschler, eds. Investing in Resource Efficiency: The Economics and Politics of Financing the Resource Transition. Heidelberg: Springer, pp. 227-243. https://doi.org/10.1007/978-3319-78867-8_11

53. Rozmahel, P., Grochová, L. I. and Litzman, M., 2014. Evaluation of Competitiveness in the European Union: Alternative Perspectives. Procedia Economics and Finance, 12(March), pp. 575-581. https://doi.org/10.1016/S22125671(14)00381-5

54. Sakamoto, T. and Managi, S., 2017. New evidence of environmental efficiency on the export performance. Applied Energy, 185, pp. 615-626. https:// doi.org/10.1016/j.apenergy.2016.10.126 
55. Salvatore, D., 2010. Globalisation, International Competitiveness and Growth: Advanced and Emerging Markets, Large and Small Countries. Journal of International Commerce, Economics and Policy, 1(1), pp. 21-32. https://doi. org/10.1142/S179399331000007X

56. Schröter, M., Lerch, C. and Jäger, A., 2011. Materialeffizienz in der Produktion: Einsparpotenziale und Verbreitung von Konzepten zur Materialeinsparung im Verarbeitenden Gewerbe. A report prepared for the German Federal Ministry of the Economy and Technology. Fraunhofer-Institut für System- und Innovationsforschung ISI. Karlsruhe.

57. SERI, 2013. Global Material Flow Database - Technical Report. Vienna.

58. Siggel, E., 2006. International Competitiveness and Comparative Advantage: A Survey and a Proposal for Measurement. Journal of Industry, Competition and Trade, 6(2), pp. 137-159. https://doi.org/10.1007/s10842-006-8430-x

59. Snowdon, B. and Stonehouse, G., 2006. Competitiveness in a Globalised World: Michael Porter on the Microeconomic Foundations of the Competitiveness of Nations, Regions, and Firms. Journal of International Business Studies, 37(2), pp. 163-175.

60. Sorrell, S., 2003. Carbon Trading in the Policy Mix. Oxford Review of Economic Policy, 19(3), pp. 420-437. https://doi.org/10.1093/oxrep/19.3.420

61. Sudhakara Reddy, B., 2013. Barriers and drivers to energy efficiency - A new taxonomical approach. Energy Conversion and Management, 74, pp. 403416. https://doi.org/10.1016/j.enconman.2013.06.040

62. UNCEEA, 2018. AREA C: Establishing global SEEA-related databasesUpdated roadmap and next steps - UN Committee of Experts on Environmental-Economic Accounting (UNCEEA). New York.

63. UNEP IRP, 2010. Assessing the Environmental Impacts of Consumption and Production - Priority Products and Materials. A Report of the Working Group on the Environmental Impacts of Products and Materials to the International Panel for Sustainable Resource Management. Hertw.

64. UNEP IRP, 2014. Decoupling 2 - Technologies, Opportunities and Policy Options. Nairobi: United Nations Environment Programme..

65. UNEP IRP, 2016. Global Material Flows and Resource Productivity. Assessment Report for the UNEP International Resource Panel. Nairobi: United Nations Environment Programme.

66. UNEP IRP, 2017. Resource Efficiency: Potential and Economic Implications. Nairobi: United Nations Environment Programme.

67. van Ewijk, S., 2018. An Introduction to Resource Efficiency: Concepts and Definitions. In F. Flachenecker and J. Rentschler, eds. Investing in Resource Efficiency: The Economics and Politics of Financing the Resource Transition. Heidelberg: Springer, pp. 13-28. https://doi.org/10.1007/978-3-319-78867-8_2

68. Varian, H., 2010. Intermediate Microeconomics: A Modern Approach. New York.

69. Voinescu, R. and Moisoiu, C., 2015. Competitiveness, Theoretical and Policy Approaches. Towards a More Competitive EU. Procedia Economics and Finance, 22, pp. 512-521. https://doi.org/10.1016/S2212-5671(15)00248-8 
70. von der Leyen, U., 2019. A Union that strives for more - My agenda for Europe. Brussels.

71. Walz, R., 2011. Employment and structural impacts of material efficiency strategies: results from five case studies. Journal of Cleaner Production, 19(8), pp. 805-815. https://doi.org/10.1016/j.jclepro.2010.06.023

72. Wilts, H. and Bleischwitz, R., 2012. Combating Material Leakage: a Proposal for an International Metal Covenant. Sapiens, 4(2), pp. 1-9.

73. World Bank, 2013. World Development Report 2014 - Risk and Opportunity: Managing Risk for Development. Washington DC: The World Bank. 